\begin{tabular}{|c|c|c|c|}
\hline & 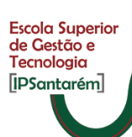 & 卧 & $\begin{array}{l}\text { ISSN 2029-7564 (online) } \\
\text { SOCIALINĖS TECHNOLOGIJOS } \\
\text { SOCIAL TECHNOLOGIES } \\
2014,4(1) \text {, p. } 7-24\end{array}$ \\
\hline
\end{tabular}

\title{
CONVERGENCE TO THE EUROPEAN ENERGY POLICY IN EUROPEAN COUNTRIES: CASE STUDIES AND COMPARISON
}

\author{
César Teixeira \\ CISTER/INESC-TEC, ISEP, Portugal, crdst@isep.ipp.pt \\ Michele Albano \\ CISTER/INESC-TEC, ISEP, Portugal, mialb@isep.ipp.pt \\ Arne Skou \\ Aalborg University Denmark, ask@cs.aau.dk \\ Lara Pérez Dueñas \\ GNARUM, Spain, lara.perez@gnarum.com \\ Francesco Antonacci \\ eZmonitoring, Ireland, francesco.antonacci@ezmonitoring.eu \\ Rodrigo Ferreira \\ ISA, Portugal,rferreira@isa.pt \\ Keld Lotzfeldt Pedersen \\ Energi Nord Denmark, kp@energinord.dk, \\ Sandra Scalari \\ ENEL, Italy, sandra.scalari@enel.com \\ doi:10.13165/ST-14-4-1-01
}

\begin{abstract}
Purpose - our paper aims at analysing how different European countries cope with the European Energy Policy, which proposes a set of measures (free energy market, smart meters, energy certificates) to improve energy utilization and management in Europe.


Design/methodology/approach - The paper first reports the general vision, regulations and goals set up by Europe to implement the European Energy Policy. Later on, it performs an analysis of how some European countries are coping with the goals, legal, economical and regulatory measures. Finally, the paper draws a comparison between the countries to present a view on how Europe is responding to the emerging energy emergency of the modern world.

Findings - our analysis on the cases of different use (countries) has shown that European countries are converging to a common energy policy, even though some countries appear to be later than others. In particular, Southern European countries were slowed down by the global financial and economical crisis. Still, it appears that contingency plans were put into action, and Europe as a whole is proceeding steadily towards the common vision.

Research limitations/implications - European countries are applying yet more cuts to financing green technologies, and it is not possible to predict clearly how each country will evolve its support to the European energy policy. Moreover, we have only analysed a small number of countries. At the same time, we have selected countries belonging to different areas of Europe, and we consider that the countries selected as placeholders for the groups cover the whole normative spectrum that can be found in Europe.

Practical implications - Different countries applied different measures to attain the targets set by the European Union. The implementation of the European energy policy has to cope with the resulting plethora of regulations, and a company proposing enhancement regarding energy management still has to possess robust knowledge of the single country, before being able to export experience and know-how between European countries.

Originality/Value - Even though a few surveys on energy measures in Europe are already part of the state-of-the-art, organic analysis diagonal to the different topics of the European Energy Policy is missing. Moreover, this paper highlights how European countries are converging on a common view, and provides some details on the differences between the countries, thus facilitating parties interesting into cross-country export of experience and technology for energy management.

Keywords: energy management; energy market; energy certificates; smart meters.

Research type: research paper / use cases.

\section{Introduction}

The electrical power grid, or often called 'the grid', is an interconnected network for delivering electricity from suppliers to consumers. It consists of generating stations that produce electrical power (production domain), high-voltage transmission lines that carry power from distant sources to demand centres (transmission domain), and distribution lines that connect individual customers (distribution domain). 
The activities of transmission and dispatching are subject to technical constraints, mainly regarding balancing the volumes of electricity injected into the grid and those withdrawn from the grid. Novel requirements for the grid have emerged in recent years, and in particular our society is nowadays headed into becoming a low consumption economy based on more secure, more diverse, more competitive and more sustainable energy. At a European level, the '20/20/20' commitments (Capoor and Ambrosi, 2007) agreed under the EU Climate Change and Energy Package set three new targets for 2020:

- A minimum 20\% reduction in GHG emissions based on 1990 levels,

$-20 \%$ of final energy consumption to be produced by renewable energy resources,

$-20 \%$ reduction in primary energy use, compared with projected levels to be achieved by improving energy efficiency.

In the last decade, a number of decrees have changed the way the grid works to implement this vision, and in particular much work has been done to create a European energy market and integrate renewable sources and distributed energy production into the grid, with the goal to improve efficiency and competitiveness, while taking into account supply security and protection of the environment.

To stimulate the fairness of the energy market, the concept of unbundling (Gugler et al, 2013) was introduced in most European countries, meaning that there must be independence between the production domain and the transmission and distribution domains.

A measure to stimulate international development of renewable energy has served as an introduction to the Renewable Energy Certificate System (RECS) (Fouquet, 2013), which creates a correlation between the power being sold and its environmental impact. A certificate is a documentation of how power has been produced, and it makes it possible to certify that a percentage of the sold energy has been produced from renewable energy sources.

Finally, under EU legislation, $80 \%$ of consumers will need to have smart meters (Gans et al, 2013) installed by 2020 as part of a larger plan to help European nations meet energy-efficiency targets. The smart meters will allow:

- Set up of different tariffs depending on date and time,

- Active demand response from the user,

- Remote reading and managing.

This paper firstly details the European regulations, and the goals set up by Europe. Later on, it performs an analysis of how some European countries are coping with the goals, with both financial and legal and economical and regulatory measures, and finally draws a comparison between the countries to present a view on how Europe is responding to the emerging energy emergency of the modern world.

\section{European approaches to energy management}

Without losing generality, we can consider that the grid is divided into three different layers, national grid and regional grid, which are part of the transmission domain, and local grid, which is part of the distribution domain. 
- The nationwide grid transports electricity from one area of the country to another and operates at high voltage, typically at voltage level of $400-100 \mathrm{kV}$. Large power plants are connected to the national grid.

- The regional grid transports power from the national grid up to the local area distributions grids and operates at middle voltage, typically at voltage level of 130-5 kV. Decentralised power plants, business plants and wind farms are typically connected to the regional grid. Large industrial consumers can have a connection to the regional grid.

- The local grid distributes power to normal consumers and operates at low voltages, typically at $400 \mathrm{~V}$. Small local photovoltaic (PV) systems and wind mills are connected to the local grid.

Within the grid, the activities of transmission and dispatching are subject to very strict technical constraints, mainly regarding instantaneous and continuous balancing of the volumes of electricity injected into the grid and those withdrawn from the grid (Vandezande et al, 2010), taking into account transmission and distribution losses, keeping the frequency and voltage of electricity within a very narrow range, and ensuring that the power flows on each line do not exceed the maximum admissible transmission capacity. Even minimum deviations from any of the above parameters for more than a few seconds may rapidly trigger critical conditions in the power system.

In Europe, further requirements on energy saving, environmental preservation and secure energy provision were chased by means of decrees, which set up constraints for grid participants. The European goals regarding energy were defined in Communication from the Commission to the European Council and the European Parliament - an energy policy for Europe (2007), which stated that.

"A European Energy Policy will firmly commit the European Union (EU) to a low consumption economy based on more secure, more competitive and more sustainable energy. Priority energy objectives involve ensuring the smooth functioning of the internal market in energy, security of strategic supply, concrete reductions in greenhouse gas emissions caused by the production or consumption of energy and the EU's ability to speak with a single voice on the international stage." [ibid.].

The European Energy Policy has been reviewer many times, for example in Kanellakis (2013), and its main goals are to:

- Set up of a European energy market, at least at the wholesale level. This goal was pursued by issuing Directive 2009/72/EC, which defined common rules for the electricity markets, with the goal of facilitating cooperation between countries and fair competition between energy providers, to benefit the final customer.

- Ensure a secure energy supply, by stimulating the adoption of diverse supply sources for both non-renewable and renewable energy.

- Reduction of greenhouse gas emissions, pursued by obligations for the Member States to cut $30 \%$ of emissions in already developed countries, to reach an overall reduction of $20 \%$ of gas emissions, with respect to the 1990 levels. Moreover, the European overall energy consumption aims at a $20 \%$ reduction, and at producing at least $20 \%$ of the total used energy by means of renewable sources. 
In particular, the EU Third Energy Package (2009) proposed a few common rules to facilitate competition in the energy market, in particular by suggesting the adoption of unbundling in each country, through implementing any one of the following proposals:

- Full unbundling: prohibition for transmission operators to act as energy producers, and vice versa;

- Independent system operator (ISO): allows transmission networks to remain under the ownership of energy groups, but transfers operation and control of their day-to-day business to an independent system operator, to remove conflicts of interest. Investments on the network will be accomplished not only by the owner's funding but also by that of the ISO management.

- Independent transmission operator (ITO): energy companies can retain ownership of their transmission networks, but the transmission subsidiaries would be legally independent joint stock companies operating under their own brand name, under a strictly autonomous management and under stringent regulatory control. However, investment decisions would be made jointly by the parent company and the regulatory authority.

Another measure to stimulate international development of renewable energy has been the introduction of the Renewable Energy Certificate System (RECS). It advocates the use of a standard energy certificate to provide evidence of the production of a quantity of renewable energy, and provides a methodology which enables renewable energy trade, allowing the creation of a market for renewable energy and promoting renewable energy in Europe. A RECS energy certificate is issued for every 1 megawatthour $(\mathrm{MWh})$ of renewable energy produced by an electricity generation facility that has been registered with the relevant national RECS issuing body. These certificates can be transferred between market parties in different countries, and are used to provide evidence of renewable energy production. The certificates can be traded and form a marketplace of their own, detached from the power market. (Tsao et al, 2011)

The power market is divided into wholesale and end-user markets (retail market). The wholesale market embraces generators, suppliers, big industrial enterprises and other large undertakings. The retail market sells to end-users and supply companies. Small end-users normally buy power from an electricity supply company, while larger end-users, such as industrial enterprises, often buy directly in the wholesale market. The request and supply on the market ends up defining the price of the exchanged energy. (European Commission „Energy prices and costs in Europe“, 2014)

Distributed generation can be integrated into the energy grid in different ways and the main approaches are: allowing the customers to consume the energy that they have produced, or allowing them to sell the energy to one bulk energy producer, or to sell the energy even to other final customers. As it will be seen below, European countries have adopted different integration paradigm, depending on the level of liberalisation of the energy market they possess.

Next sections will provide highlights on how some European countries are supporting the European goals. 


\section{Spain}

Spain has adopted the same energy commitments of Europe (Communication from the Commission to the European Council and the European Parliament - an energy policy for Europe, 2007), still the adoption of green technologies was severely slowed down by the economical crisis faced by the country.

Unbundling in the wholesale market was introduced through the Electric Power Law of 1997 (Law 54/1997), which opened up Spanish power market to competition by imposing unbundling. However, companies are permitted to form groups that undertake both generation and transmission, provided that the company performs regulated activities with real separation at decision-making level (legal and functional unbundling) (Spanish Energy Regulator's annual report to the European commission, 2011).

Spanish and Portuguese day-ahead and intraday electricity markets are fully integrated in the MIBEL (Mercado Ibérico de Electricidad). When there is congestion in the Portugese-Spanish interconnection, the MIBEL is split into two price areas (zone price with market splitting). Price convergence is quite high, for example, in 2010 prices in the Spanish area have been equal to those of the Portuguese area for $80 \%$ of the hours. (Communication from the Commission to the European Council and the European Parliament - an energy policy for Europe, 2007). Spain, Portugal and France form the South-West Europe electrical region, and actions are being taken to improve cross-border exchange capacity between Spain and France.

Regarding the retail electricity market, in Spain there are about 28 million consumption points with a power $<15 \mathrm{~kW}, 95 \%$ of which are domestic users. This represents $35 \%$ of total electricity consumption. (ibid.). The "Supplier Switching Office" (OCSUM) was set up with the aim of monitoring and facilitating supplier switching procedures. Switching period deadlines (few days) are regulated. As a result of unbundling, the user signs two different contracts with the chosen electricity supplier and the distribution company.

The distribution system operators are in charge of metering. In the past, for bigger consumers (>15 KV) hourly reading was compulsory, whereas for the rest of the customers the reading was generally conducted every 2 months. The Measurement Equipment Substitution Plan (ITC Order number 3860/2007) established a calendar for introducing smart metering in Spain for every consumer. In 2018, all 27 million Spanish meters are expected to be smart meters.

Spain has been one of the first countries to support the usage of RECS. Regarding distributed energy generation, there has been a huge increase in the number of generation points in Spain, from some more than 5,000 generation points in 2004 to more than 60,000 in 2011. Self-consumption for grid-connected facilities has been enabled in 2011 through Royal Decree 1699/2011, but with some limitations, for example, the obligation for the energy producer and consumer to be the same (no energy exchange is allowed in this context).

After an unexpected boom of photovoltaics in 2008, the retribution for distributed energy production has been decreasing, to try to "contain" the 2008 boom. In the wake of the 2008 financial crisis, the Spanish Government has drastically cut its subsidies 
for solar power, and now in an unprecedented move it wants to make consumers pay for the electricity that they generate and use themselves. Moreover, regulation uncertainty, as well as large amount of administrative procedures have been a strong barrier against optimal development of distributed generation.

\section{Germany}

The German electricity market has been fully liberalised since 1998, at both wholesale and retail levels. (Genoese et al, 2010). More than half of the wholesale volume was traded over broker platforms and more than a third of the trade volume was accounted for by bilateral transactions between parties.

After German EEX (European Power Exchange) and French Powernext joined their market activities in 2009, the so-called 'Trilateral Market Coupling' area (TLC: France, Belgium, Netherlands) has been extended to Germany in 2010, forming the Central West European (CWE) area. The market model applied is zonal pricing with a market coupling mechanism, which means that area price is calculated for each country, with price convergence when the transmission capacity is sufficient.

Germany was included in 2008 in the Nord Pool Spot intraday (Kanellakis et al, 2013) with the target to intensify cooperation between the Nordic countries and the CWE countries to full price coupling in 2012 using a single price coupling algorithm.

The $20 \%$ of the total electricity generation in 2011 was due to renewable energy sources. After the Fukushima disaster in March 2011, the German government U-turned its stance on nuclear energy and announced it would begin terminating all nuclear plants in the country. Compensation is being achieved through thermal (nonintermittent), with the construction of new coal-based power plants and renewables (intermittent energy sources).

Germany's National Renewable Energy Action Plan foresees a renewable energy share of $38.6 \%$ by 2020 . Thus, the shares of electricity generated from renewable sources will more than double between 2010 and 2020, with a focus on wind turbines. (Traber and Kemfert, 2011)

Today around half of all German household customers are still supplied by universal supply, which tends to be the most expensive supply. Approximately $45 \%$ of all household customers who switch supplier are acquired by one of Germany's four largest suppliers. Retail prices for electricity are not regulated.

Germany has created systems of trade to ensure that the goal of promoting RECS can be met. At the same time, Germany currently uses about 48 million traditional electric meters. Germany has no official policy on the adoption of smart meters. It is unlikely that Germany will follow the smart meter rollout recommendations of the $\mathrm{EU}$, because installing the devices would be too expensive.

There is an indirect policy incentive for self-consumption of renewable energy, which provides a premium to users consuming the energy they themselves produce, and the premium is higher when self-consumption is more than $30 \%$ of production. Operators of PV installations may sell electricity directly to third parties and it is explicitly fostered by German regulation, provided that this is announced to the grid operator one month in advance. 


\section{France}

The French energy sector (Commission de Régulation de l'Énergie, 2011) has traditionally been dominated by high share of nuclear power, while renewable sources had no significant growth during the last 20 years. Due to extensive hydro resources, France began from a substantial share of renewable electricity, which was $14.8 \%$ in 1990 and almost the same (14.9\%) in 2010 (including big hydro). Nuclear power represents $74.2 \%$ of the generation mix (2010), while fossil fuels only account for $10.8 \%$.

The French wholesale market is characterised by a high degree of concentration and with the incumbents exerting significant market power. For example, the main energy producer in France is EDF, which delivers $91 \%$ of the installed power. Starting in 2001, after a decision of the European Commission, EDF launched a number of auctions to sell off virtual power plant capacity to company that would act as energy resellers, still EDF maintained its dominant position.

The French transmission system operator is RTE (Réseau de Transport d'Électricité), a subsidiary of EDF. RTE was established in 2000 as a result of the unbundling European Directive, earlier EDF was controlling all generation and transmission activities.

The dominating French distribution system operator is ERDF (Électricité Réseau Distribution France), which is $100 \%$ controlled by EDF and is responsible for $95 \%$ of the French distribution grid. The remaining $5 \%$ are operated by 160 local electricity distribution enterprises.

France opened its retail markets to competition in 2007, allowing all consumers to choose their electricity supplier in the free market. The French retail electricity market is highly concentrated and in 2010 , still $93.6 \%$ of the consumption sites were supplied by the 3 historical suppliers.

France supports the RECS system (Sustainable Real Estate Roundtable, 2011) and, as far as smart meters are concerned, it is estimated that $95 \%$ of meters will be replaced by smart meters by 2016 .

Self-consumption of electricity produced by independent producers is legally permitted if duly authorised by or declared to the relevant administrative authority; however, only "for their own use". Resale to any other legal entity, such as tenants or neighbours is not authorised. The purchase scheme of the surplus of electricity fed into the grid is mandatory, and EDF or the local distributor is obliged to sign an electricity purchase agreement with the facility owner.

\section{Denmark}

In 2012 the Danish Government parties and all opposition parties, except one, signed an energy agreement, whose primary focus is macro transition to greener production and behaviours, a goal to be achieved throughout the society via energy saving initiatives and by using more renewable energy in the form of wind, biogas and biomass. Thus, in Denmark there is a requirement that $50 \%$ of the total Danish electricity consumption in 2020 comes from wind turbines and that Denmark is 
independent of fossil fuels in 2050 (Mathiesen et al, 2011). The majority of the economic space of the agreements is used for massive investment in onshore and offshore wind turbines. There are approximately 5,400 wind turbines in Denmark, and they currently represent most of the country's energy production from renewable energy sources, after the quantity of produced GWh increased by around $20 \%$ per year for 10 years.

Denmark has two separated transmission systems, of which the eastern one is synchronous with the Nordic one (Germany, Sweden and Norway) and the western one with the synchronous grid of Continental Europe. The Great Belt Power Link connecting the two systems was commissioned in July 2010 and started commercial operations in August 2010. The distribution systems are owned and operated by local "grid companies", among them 10 cover up most of the total energy distribution.

The grid companies are in charge of the measuring and responsible for correct and safe installation of the meters and that the meters are read at least once a year. The trend in Denmark is that more and more grid companies choose to replace the old meters with new smart meters. By 2020, the grid companies in Denmark have to install intelligent meters at all measuring points.

In the case of distributed energy production, an energy producer sells the electricity either directly to an electricity supplier or to Nord Pool, which is the Nordic power exchange. The prosumer sells or buys electricity from Energinet.dk in the regulating power market, to enable Energinet.dk to maintain the balance in the electricity system and ensure the security of supply.

The development, in Denmark, of renewable sources having a nominal installed power at maximum $6 \mathrm{~kW}$ has exploded in the recent years. In fact, the number of solar plants registered at Energinet.dk passed from 2700 at the end of 2011 to more than 20000 at end of 2012. If the prosumer annually consumes more energy than it produces, at the end of the year it will pay for the difference only, at normal energy price. If more energy is produced than consumed, one will receive a fixed-rate payment, which is generally lower than the price for buying energy.

Before the liberalisation of the electricity market, end users had to buy electricity from the sole electricity supplier located in the area where the end user lived. From January 2003, an end user has the right to change from one electricity supplier to another. There are many approved electricity suppliers on the Danish market, which buy electricity either at a power exchange (e.g. Nord Pool) or directly from an electricity producer, and deliver energy to the end-user. On an annual basis, about $6 \%$ of the electricity customers are switching supplier. Finally, Denmark fully supports the RECS (Sustainable Real Estate Roundtable, 2011).

\section{Sweden}

The structure of the Swedish electricity grid articulated into usual parts:

- Generation: $90 \%$ of the Swedish electricity is produced by hydropower, nuclear power and CHP. It is only the largest production facilities and the regional grids that are connected to the national grid. 
- National grid: Svenska Kraftnät, a state-owned public utility, administers and runs Sweden's national grid and is the Transmission System Operator (TSO) in Sweden. The customers at the main grid are the grid operators of the regional grid.

- Regional grid: The regional grid is still part of the transmission domain, and it is an intermediate step between the national grid, which transports energy over long distances, and the local grid, to which the final users are attached. There are three main owners of the regional grid in Sweden. Energy-intensive companies, such as smelters and paper mills are often connected to the regional grid.

- Local grid: The local grid operators take over from the regional grid operators and deliver electricity to the small industries, households and other users. The local grids or distribution grids are owned by the regional grid companies or other companies with local relations. There are 170 grid operators in Sweden. Each local grid operator within its geographic area has an exclusive right to provide electricity to the customers.

In January 1996, the Swedish electricity market and all network operations were separated from generation and trading. Consumers pay for two separate services - production and handling of electricity on the commercial side, and the physical transportation over the grid. The consumer buys electricity from one supplier. Electricity suppliers buy electricity on the Nordic power exchange Nord Pool (currently, $70 \%$ of total power), or directly from an electricity generator (currently, $30 \%$ of total power).

The retail market is divided into 4 areas, and this has no influence on the free choice of electricity supplier, but the electricity price is affected. In fact, customers in the south of Sweden tend to pay higher price than customers in the north of Sweden, since the production in Northern Sweden is higher than consumption, while the consumption in Southern Sweden is higher than the production.

In Sweden, it was possible to choose a contract with or without an environmental agreement, with the aim to promote development towards a more sustainable electricity generation. From 1 May 2003, payment for renewable electricity production is replaced by the system of energy certificates.

In 2009 , Sweden was the first country to complete installing smart meters for all its customers.

\section{Norway}

The Norwegian electricity grid has basically the same structure as the Danish and Swedish grids, with main, regional, and local grid.

Norway is the sixth largest hydropower producer in the world, and in a year with normal precipitation hydropower generation corresponds to approximately $99 \%$ of Norway's total power production. In addition to hydropower, Norway has wind power stations, thermal power plants, and gas-fired power plants.

Many power plants can store water in reservoirs and are referred to as reservoir power plants. The reservoirs allow water to be retained in flood periods and released in drought periods, typically in the winter. Water is collected in the reservoirs when inflow is high and consumption low. Normally, water will be drawn off during autumn 
and winter, when electricity demand is the highest. In spring and summer, electricity demand reaches its lowest level, and the reservoirs refill.

Statnett is the main TSO of Norway and is responsible for the Norwegian main grid - with the duty to ensure that this network is open to all players in the electricity market. Statnett is the owner of approx. $90 \%$ of the national grid. A company who provides or consumes power from the main grid pays a transport price in accordance with the commercial agreement.

Consumers can choose their electricity supplier. At the same time, since in Norway construction of grids is particularly expensive, grid management and operation have been defined as a natural monopoly, where users are tied to their local distribution company. The sector has not been opened up to competition, and the authorities regulate the activities. The regulation, described as monopolistic regulation, is intended to safeguard consumer rights, a well-functioning power market and ensure efficient management and development of the grid.

The grid manager is responsible for the metering, and by the end of 2018 all the meters should be changed to smart meters. Norway fully supports RECS.

\section{Italy}

The structure of the electrical system before market liberalisation was "vertically integrated", in the sense that the entire national system of production, import, transmission, distribution and sale of energy was owned by one company only (ENEL).

In 1999, Decree No. 79/99 (Bersani Decree) has forced the unbundling of various subsystems that make up the national electricity system. The generation and import activities have entered the free market, and now anyone can produce and import energy. In order to facilitate the creation of the market with more operators, the ENEL monopolistic position has been reorganised through selling some production plants. ENEL currently contributes to around 40\% of Italy's energy production, while Edison, Sorgenia, A2A and Iride Group compete for the remaining part of the Italian market.

Being of national interest, transmission and dispatching activities are regulated for both price fairness and to ensure universal access to the network. The operator also has the obligation of grid maintenance and extension. Currently, the transmission grid is privatised but government-controlled and owned by one company only, namely Terna Rete Elettrica Nazionale SpA, which is part of the ENEL group and is the first European TSO for kilometres of electricity lines managed.

Distribution activities, which are also of national interest, are not carried out in free market conditions, but are instead given in grants from the state to different operators through public tender, for a period not exceeding twelve years.

The Italian Power Exchange (Ipex) is the electronic venue for trading in wholesale electricity, where the electricity price corresponds to the clearing price resulting from the intersection between the volumes of electricity demanded and offered by its participants.

Before market liberalisation, end users could purchase the energy exclusively from the only distributor (ENEL). From 1 July 2007, anyone is free to choose their own energy supplier. 
Italian renewable energy plants (Magnani and Voana, 2013) appear to have doubled the GWh of produced energy in 2008-2011. Incentive programmes for photovoltaic (PV) installations are designed to provide the basis for medium to longterm growth, with the goal of grid parity by the end of 2016, meaning that the cost of $\mathrm{PV}$-produced energy will be the same as that of fossil-based energy.

Distributed generation is supported by regulations, and energy producers can self-consume energy and sell it to the grid, with a rate depending on the power plant size.

Italy supports RECS. The energy efficiency certificates (Italian acronym TEE) are compulsory to electricity and gas distributors, and can be purchased from the RECS market or directly from renewable energy producers. In order to be able to send their energy, fossil energy producers must buy enough energy certificates to simulate that a percentage of the sold energy was produced by renewable means.

From 2001, ENEL has been replacing the old meters with the new smart ones. Between 2000 and 2005, ENEL Distribution deployed smart meters to its entire customer base.

\section{Portugal}

The national Decree-Law no. 172/2006 implemented the European Electricity Directive and established the new legal framework for the Portuguese electricity sector („The Portuguese Electricity System“). The generation and supply of electricity and management of the organised electricity markets are now fully open to competition, subject to obtaining the requisite licenses and approvals. However, the transmission and distribution components of the electricity industry continue to be provided through the award of public concessions.

Electricity generation is divided into two regimes: ordinary regime and special regime.

- Special regime relates to the generation of electricity from renewable sources (except large hydropower plants). Special regime generation is subject to different licensing requirements and benefits from special tariffs. A supplier, EDP Serviço Universal, is obliged to purchase electricity generated under the Portuguese special regime.

- Ordinary regime refers to bulk production of electricity. EDP has retained the rights to operate the 26 large Portuguese hydropower plants, with the concessions having different expiration date, until on average 2047.

Electricity transmission activities are carried out through the national transmission grid, under an exclusive concession granted by the Portuguese government. Presently, the exclusive concession for electricity transmission has been awarded to REN Rede Eléctrica by article 69 of Decree-Law 29/2006, following the concession already awarded to REN Rede Eléctrica by article 64 of Decree-Law no. 182/95 of 27 July. The national distribution grid is operated through an exclusive concession granted by the Portuguese Government. This exclusive concession is held by EDP's subsidiary EDP Distribuição. 
The retail market was progressively opened between 1995 and 2006. From 4 September 2006, all consumers in mainland Portugal have been able to choose their electricity supplier, without any additional fee for switching suppliers. Suppliers may openly buy and sell electricity, and have the right of access to the national transmission and distribution grids upon payment of the access charges set by the Portuguese Energy Services Regulatory Authority (Entidade Reguladora dos Serviços Energeticos, "ERSE"), which is an autonomous public entity.

In 2001, the Portuguese Government published a resolution with several energy efficiency measures, and described the objective to "support the progressive implementation of telemetering for electricity, water and gas as a strategy for distribution network and quality service improvement". Moreover, during 2001 the Portuguese and the Spanish Governments took the first steps towards the Electricity Iberian Liberalised Market (MIBEL) where both Portuguese and Spanish consumers could buy electricity freely from any agent in the market. MIBEL became fully operational on 1 July 2007. Technical agreements specified by MIBEL include the compulsory installation of digital meters for new facilities since July 2007, and the replacement of all traditional meters (6 million in Portugal) by smart meters. Portugal started in March 2011 with large-scale implementation of Smart Electricity Grid Smart Grid - in charge of a consortium led by EDP Distribuição. It is intended to cover six million of all customers until 2017 (da Silva, 2011).

Portugal is one of the EU countries most dependent on fuel imports $(76.7 \%$ in 2010). The share of renewable energy consumed in Portugal totalled $22.8 \%$ in 2010, and hydropower is the main renewable energy source. There is not much distributed energy production, and wind power dominates it (Amorim, 2013). RECS are not supported yet, and discussions are still ongoing regarding how and when they will interact with the Portuguese energy system.

\section{Great Britain}

GB has put much effort into following the European Directives to implement the European Energy Policy, and it has been one of the first countries to create trade systems to support and promote RECS.

GB has set up its own, more ambitious goals, and aims to lower energy consumption by $15 \%$ and produce $30 \%$ of GB electricity from renewable sources by 2020 , starting from a $10 \%$ of renewable energy in 2009.

The GB electricity sector was one of the leaders of the global and GB trend towards liberalisation and privatisation of network industry that started in the 1980s under the Conservative Government. The privatisation of the GB electricity sector started in 1990, and the GB electricity market was fully open to competition (including households) by 1998, leading to all users being allowed to choose their supplier by 1999. Price controls were gradually lifted, and by 2002, when the last controls were removed, Britain had perhaps the most liberal energy market in Europe.

14 regional monopolies became five companies and together with British Gas became known as the "Big Six". Since the market opening, 16 companies have entered under their own licence. Seven of these remain, supplying a total of $2 \%$ of GB 
households. No company without links to the period before liberalisation has been able to gain a foothold in the market. Incumbency seems to be a powerful weapon. Herd-like pricing behaviour also suggests little worry about smaller, newer companies taking customers from the Big Six.

Since 2002, the Renewables Obligation (RO) is GB's main mechanism for supporting merchant generation of renewable electricity. Each electric supplier has got to provide at least a fixed percentage of renewable electricity, or pay a penalty of $£ 34.30$ ( $€ 50.58$ ) per MWh. The percentage of renewable power that must be supplied is $7.9 \%$ and will increase to $15.4 \%$ by 2015 .

Suppliers buy energy from the wholesale market or directly from generators and arrange for it to be delivered to end consumers. The price they ask from the consumers is not regulated.

Over the coming decade, smart meters will be deployed in homes and businesses, as they are highly supported by the Government from capital grant schemes. Adoption goals are $30 \%$ coverage in 2015 and $100 \%$ in 2020 .

\section{Ireland}

Ireland has a single electricity market operator (SEMO), one transmission system operator (EirGrid) and one distribution system operator (ESB Networks). The Electricity Supply Board (ESB, from Irish: Bord Soláthair an Leictreachais) is a state owned (95\%) electricity company, whose members are appointed by the Government. It is the largest electricity generator in Ireland. While historically a monopoly, the ESB now operates in a liberalised and competitive market. The transmission system is managed by ESB subsidiary, ESB Networks Limited, and is operated by independent state company EirGrid.

The Irish electricity industry operates a single wholesale market across the whole of the island of Ireland, the Single Electricity Market or SEM, whose operation is facilitated by the Single Electricity Market Operator (SEMO). SEMO is a contractual joint venture between the two system operators - SONI in North Ireland and EirGrid Plc in the Republic of Ireland.

The Irish energy market has been fully open since February 2005, and ESB has a market share of less than 50\%. Price regulations were removed from all business markets in October 2010. In April 2011, the domestic market was totally deregulated and as a result all suppliers are now free to set their own tariffs.

Ireland's electricity market (Electric Ireland report „Micro-generation Scheme“) is an interesting case study in a variety of ways, as it perhaps could be characterised by slow initial movement toward liberalisation and then rapid catch-up. Ireland's national vertically-integrated incumbent, the ESB, has retained the majority of generation share and retail customer shares up until mid-to-late 2007, when additional policies came into play. At first, retail competition was slow to emerge in the early 2000 s, but has become robust. Full market opening was from 2005, but by 2007 about $30 \%$ of customers were with different suppliers.

Ireland is committed to a range of renewable energy and efficiency targets, many of which are being implemented as climate policy measures to reduce carbon 
emissions. While hydro was historically the largest contributor to renewable electricity in Ireland, electricity production from wind energy has now increased to the point that it accounted for $81 \%$ of the renewable electricity generated in 2011 . Wind, hydro and biomass-generated electricity in 2011, respectively, accounted for $15.6 \%, 2.5 \%$ and $1.2 \%$ of Ireland's gross electricity consumption.

The Metering Programme (NSMP) turned into being in late 2007, and it defines the timeline for smart meter deployment in Ireland. The government initially considered installing smart meters in $100 \%$ of customers' homes, but later on the target appeared to be too ambitious and, following the European agenda, the new target is to substitute $80 \%$ of current meters with smart meters by 2020 .

Distributed generation is supported. Every energy producer is given a daily dispatch schedule, which specifies the power to be exported to the grid. Generators are then paid a capacity payment in compensation for their availability to generate above their scheduled dispatch, or are fined if they do not cope with their obligations. RECS are fully supported.

\section{Comparison}

The findings reported in the previous sections are summarised in Table $1^{\star}$. Some information was integrated with the data from (Epex Spot P European Power Exchange).

Table 1 performs a rough comparison of the countries analyzed in previous sections, and aims at identifying the potential risks that each country takes while heading towards the green society of the European energy policy.

All the considered European countries support the European energy policy, and some countries set even higher target for energy saving and green energy production than the compulsory ones. All countries formally performed the unbundling of energy production from energy transmission, still some countries, in particular France, UK and Ireland, have incumbents that monopolise the area. Moreover, Norway and Sweden consider that the extension and low population of their countries make the deployment of transmission infrastructure too expensive, and thus conceded monopoly regarding energy transmission and distribution. Finally, Portugal and Italy interfere with the free market by allowing energy transmission and distribution to a few companies only (concession-based).

The condition of the countries in terms of energy politics are reflected by the aggregation of the energy markets of similar countries into larger markets: "MIBEL" is the market for the Iberian peninsula, "Nordic" hosts Nordic countries, "CWE" and "NWE" are respectively for countries in the central west and north west of Europe. This aggregation is more of a political than technological nature, and in fact it does not present correlation with the kind of green energy prevalent in a country, but is reflected on the normative for distributed generation.

\footnotetext{
* Table 1 is presented at the end of the paper.
} 
Common characteristics of all European countries are the support for energy certificates, and the planned deployment of smart energy meters to energy users, with the exception of Germany.

\section{Conclusion}

This paper analysed the regulations that the European countries considered to adopt, with the goal of respecting the European targets on the matters of integration of renewable energy sources into the electricity grid and energy market fairness. According to the analysis, some countries appeared more advanced than the others. Still, nowadays most European countries appear on track, and the few exceptions, belonging to the South of Europe, are catching up.

In particular, the Nordic countries appear well on track to reach the European targets in terms of energy saving and green energy integration by 2020. Other countries suffer from different problems, and in particular Italy, Spain and Portugal are all slowed down by heavy bureaucracy that impedes a proper development of green technologies, and by the lack of funding caused by the international financial crisis that started in 2008. Finally, Italy, UK and France are in a situation close to monopoly even if they all adhere formally to the unbundling of energy production from energy transmission.

We believe that this work contributes the highlights that can be used as the basis for analysing proposals for novel regulations, and to discuss the adoption of novel technologies that match the current trends of a given country, for example solutions based on the paradigm of the smart grid. (Albano et al, 2013)

\section{Acknowledgement}

This work was supported by EU Artemis JU funding, within the ENCOURAGE project, JU grant No 269354, and by National Funds in Denmark, Portugal (through the Portuguese Foundation for Science and Technology, ref. ARTEMIS/0002/2010) and Spain in the Artemis program.

\section{References}

Albano, M. et al. 2013. "The ENCOURAGE

ICT architecture for heterogeneous smart grids", IEEE Eurocon Conference (Eurocon 2013), Zagreb, Croatia.

Amorim, F. et al. 2013. "How much room for a competitive electricity generation market in Portugal?." Renewable and Sustainable Energy Reviews 18: 103-118.
Capoor, K; Ambrosi, P. 2007. "State and trends of the carbon market 2007." World Bank, Washington, DC. Available online at: https://openknowledge.worldbank.com/ handle/10986/13406

Commission de Régulation de l'Énergie (CRE). 2011. "Rapport transmis a la DG ENER.", France, July 2011. Available online at: http:// goo.gl/sJcW9p 
Communication from the Commission to the European Council and the European Parliament - an energy policy for Europe. (2007) Available online at: http://europa.eu/ legislation_summaries/energy/european_ energy_policy/127067_en.htm

da Silva, M. 2011. "Smart Grids em PortugalPlano de Negócio para Serviço de Planeamento e Gestão Remota de Consumos Eléctricos." M.Eng. thesis, discussed on July 2011. Available online at: http://goo.gl/ C7HBAm

Directive 2009/72/EC of the European Parliament and of the Council of 13 July 2009 concerning common rules for the internal market in electricity and repealing Directive 2003/54/EC. Available online at: http://eur-lex.europa.eu/LexUriServ/ LexUriServ.do?uri=OJ:L:2009:211:0055:009 3:EN:PDF

Electric Ireland report. "Micro-generation Scheme." Available online at: https://www. electricireland.ie/ei/residential/price-plans/ micro-generation-scheme.jsp

Epex Spot - European Power Exchange. "Price Coupling of Regions." Available online at: http://static.epexspot.com/document/25391

European Commission. "Energy prices and costs in Europe." Brussels, March 17th, 2014. Available online at: http://ec.europa. eu/energy/doc/2030/20140122_swd_prices. pdf

European Commission. "EU Third Energy Package", proposed in September 2007, adopted in July 2009, available online at: http://ec.europa.eu/energy/gas_electricity/ legislation/third_legislative_package_ en.htm

Fouquet, D. 2013. "Policy instruments for renewable energy-From a European perspective." Renewable Energy 49: 15-18.

Gans, W.; Alberini, A.; Longo, A. 2013. "Smart meter devices and the effect of feedback on residential electricity consumption: Evidence from a natural experiment in Northern Ireland." Energy Economics 36: 729-743.

Genoese, F.; Genoese, M.; Wietschel, M. 2010. "Occurrence of negative prices on the German spot market for electricity and their influence on balancing power markets." Energy Market (EEM), 7th IEEE International Conference on the European.

Gugler, K; Rammerstorfer, M; Schmitt, S. 2013. "Ownership unbundling and investment in electricity markets-A cross country study." Energy Economics 40: 702-713.

Kanellakis, M.; Martinopoulos, G. and Zachariadis, T.. 2013. "European energy policy-A review." Energy Policy 62: 1020-1030.

Magnani, N.; Vaona, A. 2013. "Regional spillover effects of renewable energy generation in Italy." Energy Policy.

Mathiesen, B. V.; Lund, H.; Karlsson, K. 2011. "100\% Renewable energy systems, climate mitigation and economic growth." Applied Energy 88.2: 488-501.

"Monitoring Benchmark Report 2011", Bundesnetzagentur für Elektrizität, Gas, Telekommunikation, Post und Eisenbahnen Monitoring, Marktbeobachtung - Energie, 2011

Spanish Energy Regulator's annual report to the European commission, CNE, July 2011

Sustainable Real Estate Roundtable. "International Markets for Renewable Energy Certificates." (2012) Available online at: http://goo.gl/tIa5x2

Traber, T.; Kemfert, C. 2011. "Gone with the wind?-Electricity market prices and incentives to invest in thermal power plants under increasing wind energy supply." Energy Economics 33.2: 249-256.

Tsao, C.C.; Campbell, J. E.; Chen, Y. 2011. "When renewable portfolio standards meet cap-and-trade regulations in the electricity sector: Market interactions, profits implications, and policy redundancy." Energy Policy 39.7: 3966-3974.

“The Portuguese Electricity System." Available online at: http://www.edp.pt/en/aedp/ sectordeenergia/sistemaelectricoportugues/ Pages /SistElectNacional.aspx

Vandezande, L. et al. 2010. "Well-functioning balancing markets: A prerequisite for wind power integration." Energy Policy 38.7: 3146-3154. 
Table 1. Comparison between European countries regarding energy policies

\begin{tabular}{|c|c|c|c|c|c|c|c|c|c|c|}
\hline & Spain & $\begin{array}{l}\text { Ger- } \\
\text { many }\end{array}$ & France & $\begin{array}{l}\text { Den- } \\
\text { mark }\end{array}$ & Sweden & Norway & Italy & Portugal & $\begin{array}{l}\text { United } \\
\text { Kingdom }\end{array}$ & Ireland \\
\hline $\begin{array}{l}\text { Support } \\
\text { to Eu- } \\
\text { ropean } \\
\text { Directive }\end{array}$ & yes & yes & yes & $\begin{array}{l}\text { yes, } \\
\text { target } \\
\% \text { much } \\
\text { higher } \\
\text { than Eu- } \\
\text { ropean }\end{array}$ & yes & $\begin{array}{l}\text { yes, } \\
\text { target } \\
\% \text { much } \\
\text { higher } \\
\text { than Eu- } \\
\text { ropean }\end{array}$ & yes & yes & $\begin{array}{l}\text { yes, } \\
\text { target \% } \\
\text { higher } \\
\text { than Eu- } \\
\text { ropean }\end{array}$ & yes \\
\hline $\begin{array}{l}\text { Unbund- } \\
\text { ling }\end{array}$ & yes & yes & $\begin{array}{l}\text { yes, but } \\
>90 \% \\
\text { of gen- } \\
\text { eration, } \\
\text { transmis- } \\
\text { sion and } \\
\text { distribu- } \\
\text { tion is by } \\
\text { EDF }\end{array}$ & yes & $\begin{array}{l}\text { yes, } \\
\text { transmis- } \\
\text { sion and } \\
\text { distri- } \\
\text { bution } \\
\text { in mo- } \\
\text { nopoly }\end{array}$ & $\begin{array}{l}\text { yes, } \\
\text { transmis- } \\
\text { sion and } \\
\text { distri- } \\
\text { bution } \\
\text { in mo- } \\
\text { nopoly }\end{array}$ & $\begin{array}{l}\text { yes; } \\
\text { transm } \\
\text { \& distro } \\
\text { are con- } \\
\text { cession- } \\
\text { based }\end{array}$ & $\begin{array}{l}\text { yes; } \\
\text { transm } \\
\text { \& distro } \\
\text { are con- } \\
\text { cession- } \\
\text { based }\end{array}$ & $\begin{array}{l}\text { yes; } 6 \\
\text { com- } \\
\text { panies } \\
\text { monopo- } \\
\text { lizing the } \\
\text { market }\end{array}$ & $\begin{array}{l}\text { yes, } \\
\text { transmis- } \\
\text { sion and } \\
\text { distri- } \\
\text { bution } \\
\text { in mo- } \\
\text { nopoly }\end{array}$ \\
\hline $\begin{array}{l}\text { Energy } \\
\text { market } \\
\text { coupling }\end{array}$ & $\begin{array}{l}\text { MIBEL } \\
(2007)\end{array}$ & $\begin{array}{l}\text { CWE } \\
(2010), \\
\text { NWE } \\
(2012)\end{array}$ & $\begin{array}{l}\text { CWE } \\
(2010), \\
\text { NWE } \\
(2012)\end{array}$ & $\begin{array}{l}\text { Nordic } \\
(2000), \\
\text { NWE } \\
(2012)\end{array}$ & $\begin{array}{l}\text { Nordic } \\
(2000) \text {, } \\
\text { NWE } \\
(2012)\end{array}$ & $\begin{array}{l}\text { Nordic } \\
(2000) \text {, } \\
\text { NWE } \\
(2012)\end{array}$ & N/A & $\begin{array}{l}\text { MIBEL } \\
(2007)\end{array}$ & $\begin{array}{l}\text { NWE } \\
(2012)\end{array}$ & N/A \\
\hline $\begin{array}{l}\text { Main } \\
\text { renew- } \\
\text { able }\end{array}$ & PV & $\begin{array}{l}\text { wind } \\
\text { turbines }\end{array}$ & hydro & $\begin{array}{l}\text { wind } \\
\text { turbines }\end{array}$ & hydro & hydro & PV & hydro & wind & $\begin{array}{l}\text { wind and } \\
\text { hydro }\end{array}$ \\
\hline $\begin{array}{l}\text { Distri- } \\
\text { buted } \\
\text { genera- } \\
\text { tion }\end{array}$ & $\begin{array}{l}\text { PV boom } \\
\text { in 2008; } \\
\text { self-con- } \\
\text { sumption } \\
\text { only }\end{array}$ & $\begin{array}{l}\text { PV; in- } \\
\text { centive } \\
\text { when } \\
\text { self-con- } \\
\text { sumption } \\
>30 \% \text {; } \\
\text { energy } \\
\text { can be } \\
\text { sold }\end{array}$ & $\begin{array}{l}\text { self-con- } \\
\text { sumption } \\
\text { only }\end{array}$ & $\begin{array}{l}\text { PV; full } \\
\text { support }\end{array}$ & $\begin{array}{l}\text { biomass; } \\
\text { full } \\
\text { support }\end{array}$ & $\begin{array}{l}\text { full } \\
\text { support }\end{array}$ & $\begin{array}{l}\text { PV; full } \\
\text { support }\end{array}$ & $\begin{array}{l}\text { wind and } \\
\text { PV; EDP } \\
\text { must buy } \\
\text { produced } \\
\text { energy }\end{array}$ & $\begin{array}{l}\text { PV; dis- } \\
\text { tribution } \\
\text { is obliged } \\
\text { to buy it }\end{array}$ & $\begin{array}{l}\text { wind } \\
\text { and PV; } \\
\text { sold to } \\
\text { distribu- } \\
\text { tion at } \\
\text { fixed rate }\end{array}$ \\
\hline RECS & yes & yes & yes & yes & yes & yes & $\begin{array}{l}\text { yes; some } \\
\text { market } \\
\text { resistance }\end{array}$ & no & yes & yes \\
\hline $\begin{array}{l}\text { Smart } \\
\text { meters }\end{array}$ & $\begin{array}{l}100 \% \text { un- } \\
\text { til } 2018\end{array}$ & No & $\begin{array}{l}95 \% \text { by } \\
2016\end{array}$ & $\begin{array}{l}100 \% \text { by } \\
2020\end{array}$ & $\begin{array}{l}100 \% \\
\text { since } \\
2009 \\
\end{array}$ & $\begin{array}{l}100 \% \text { by } \\
2018\end{array}$ & $\begin{array}{l}100 \% \\
\text { since } \\
2005\end{array}$ & $\begin{array}{l}100 \% \text { by } \\
2017\end{array}$ & $\begin{array}{l}100 \% \text { by } \\
2020\end{array}$ & $\begin{array}{l}80 \% \text { by } \\
2020\end{array}$ \\
\hline $\begin{array}{l}\text { Chal- } \\
\text { lenges }\end{array}$ & $\begin{array}{l}\text { from } \\
2008, \\
\text { green in- } \\
\text { centives } \\
\text { were cut } \\
\text { out }\end{array}$ & $\begin{array}{l}\text { no } \\
\text { planned } \\
\text { adoption } \\
\text { of smart } \\
\text { meters }\end{array}$ & $\begin{array}{l}\text { no devel- } \\
\text { opment } \\
\text { of green } \\
\text { energy } \\
\text { in past } \\
10 \text { years; } \\
\text { near-mo- } \\
\text { nopoly } \\
\text { by EDF }\end{array}$ & none & none & none & $\begin{array}{l}\text { no inte- } \\
\text { gration } \\
\text { with } \\
\text { foreign } \\
\text { energy } \\
\text { market; } \\
\text { no real } \\
\text { competi- } \\
\text { tion }\end{array}$ & $\begin{array}{l}\text { no RECS } \\
\text { support; } \\
\text { heavy } \\
\text { bureau- } \\
\text { cracy }\end{array}$ & $\begin{array}{l}\text { market } \\
\text { monop- } \\
\text { oly by } 6 \\
\text { compa- } \\
\text { nies }\end{array}$ & none \\
\hline
\end{tabular}

